\title{
A NEW RECORD OF Pseudomonas marginalis CAUSING BACTERIAL BLIGHT DISEASE IN Centella asiatica(L.) Urban IN VIETNAM
}

\author{
Toan Le Thanh ${ }^{1 *}$, Hoang Nguyen Huy ${ }^{1,2}$, Narendra Kumar Papathoti ${ }^{3}$ and Natthiya Buensanteai ${ }^{2}$ \\ ${ }^{1}$ Department of Plant Protection, College of Agriculture, Can Tho University, Can Tho City, 900000, Viet Nam. \\ ${ }^{2}$ School of Crop Production Technology, Institute of Agricultural Technology, Suranaree University of Technology, \\ Nakhon Ratchasima, 30000, Thailand. \\ ${ }^{3}$ R\&D Division, Sri Yuva Biotech Pvt Ltd, Hyderabad, Telangana, India
}

https://doi.org/10.35410/IJAEB.2020.5541

\begin{abstract}
Indian pennywort (Centella asiatica (L.) Urban) is an important vegetable and medicinal herb. On the south of Vietnam, a new disease withsymptoms of bacterial blight in stems, stolons, petioles and laminasoccurred and caused severe damage at Indian pennywort fields. The purpose of this study is to identify the causal agent of the new disease and its effecton Indian pennywort at post-harvest stage. The results showed that 7 of 18 pathogen strains coded H1-1, H1-3, H2-1, H3-1, H4-4, H5-2, H6-2, caused severe blight damage. Characteristics of the bacterial strains were Gram negative, aerobicand produced fluorescence onto King's B medium, indicating thepathogen belongs to Pseudomonas genus. This bacterial Pseudomonas was positive of levan production and potato soft rot, which were confirmed that it wasPseudomonasmarginalis. This bacterial pathogenalso caused soft rot in post-harvest Indian pennywort. This is the first report ofP. marginalis on Indian pennywort in Vietnam.
\end{abstract}

Keywords: bacterial blight disease; Centella asiatica; Pseudomonas marginalis.

\section{INTRODUCTION}

Centella asiatica (L.) Urban is belong to Order Apiales, Family Apiaceae (Umbelliferae), Genus Centella[1]. The common names are Indian pennywort or Gotukola in English, and "rau ma" or "lien tien thao" in Vietnamese [1] [2]. The plant is distributed in most area of tropics and subtropics, grows in the clumps[1]. In Vietnam, the plant is grown widely [2].

The Indian pennywort is considered to be a healthy vegetable [3]. Chemical content of the Indian pennywort includes triterpene acids, volatile, fatty oil, alkaloids, glycosides, flavonoids, vitamins, amino acids and micro-nutrients [4]. Besides, the Indian pennywort is used in traditional Chinese medicine and Ayurvedic medicine to treat many kinds of diseasesincludingulcer [5], burns [6], corneal rehabilitation [7], diabetes mellitus [8], chromic, venous insufficiency, skin wounds, diarrhoea, fever, amenorrhoea [1]. In addition, the plant has good effect on improving cognition [1], relieve anxiety [1], antiepileptic [9], anti-depressant [10], memory improvement [11], protection of the gastric mucosa [12].

Diseases in Indian pennywort have been detected. Leaf spot diseaseswere recorded in many places, includingCercospora centellae in India [13] [14], Pseudocercosporacentelli in India [13], 
Vol. 5, No. 04; 2020

ISSN: $2456-8643$

Septoriacentellae in Korea [15], Alternaria sp. in India [16], Xanthomonascampestris pv. centellae[17] and Cochliobolusgeniculatus in India [18]. In addition, white rot disease by Sclerotiniasclerotiorum in India and bacterial wilt by Pseudomonassolanacearum in Sri Lanka were also reported[18] [19].

In many provinces at the south of Vietnam, a new disease of the Indian pennywort with bacterial symptoms was appeared and caused severe losses. The disease occurred in stems, stolons, petioles and laminas of the Indian pennywort. Lesions on stolons of the Indian pennywort were brown or black color with a rough surface. Its petioles and laminas turned wilting, drying and blight, then the whole plants died. The disease was at high incidence and severity when the sunlight appeared after heavy rains. Causal agent of the disease in the Indian pennywort has not yet been detected. Therefore, the research was aimed to identify the cause of the disease and its effect on post-harvest stage of the Indian pennywort.

\section{MATERIALS AND METHODS}

\subsection{Collection of disease samples}

Disease samples of Indian pennywort were collected at eighteen fields at Hau Giang, Can Tho and Tien Giang provinces, Vietnam. The plant samples were kept in paper bags after the collection. After that, the samples were stored in a $5^{\circ} \mathrm{C}$-fridge at Nedo Laboratory, Department of Plant Protection, Can Tho University, Vietnam.

\subsection{Isolation and purification of pathogen on Indian pennywort samples}

Segments of the pennywort stolon containing both parts of typical lesions and adjacent healthy tissues were selected to carry out. The segments were cut into small sections approximately 10 $\mathrm{mm}$, rinsed with sterile DI water, and sterilized with $70 \%$ ethanol for 15 to $30 \mathrm{~s}$. The stolon sections were then dried on sterile tissue papers. After that, they were put into petri plates containing water agar medium ( $2 \%$ agar), incubated at $25{ }^{\circ} \mathrm{C}$ for $24 \mathrm{~h}$. Bacterial ooze from the stolon sections were streaked onto King's B medium. Later, single colonies were selected to streak onto King's B medium until morphology of colonies was homogeneous [20] [21].

\subsection{Determination of Kock's postulateand identification on bacterial strains isolated}

The Indian pennywort without disease symptom was grown in plastic pots with sterilized soil. Each bacterial strain was inoculated on four pennywort plants. The bacterial strains isolated were cultured onto King's B medium for 4 days at $28 \pm 2^{\circ} \mathrm{C}$. After that, the bacteria were suspended in sterile DI water, which was adjusted to $1 \times 10^{8} \mathrm{CFU} \mathrm{mL} \mathrm{m}^{-1}$ by using a haemocytometer. At 20 days after planting, the pennywort plants were wounded by sterile needles, then inoculated with each suspension of bacterial strains.After that, the pots were kept in a dark inoculation room for $24 \mathrm{~h}$ at $25^{\circ} \mathrm{C}$ with relative humidity of approximately $98 \%$. After the period of inoculation, the pots were kept in a net house. Disease symptom, bacterial colony form, cell shape, flagella stain and biochemical traits were performed to complete rules of Kock's postulate[20] [22].

\section{Bacterial Gram staining}

A drop of 2-days old bacterial suspension was placed in a microscope slide. The bacteria were heat-fixed,stained following step to step with $0.5 \%$ crystal violet, Lugol's iodine, carbol fuchsin for $60,60,10 \mathrm{~s}$, respectively. Later, bacterial samples were washed with DI water, then in $95 \%$ 
Vol. 5, No. 04; 2020

ISSN: $2456-8643$

ethanol, following by DI water. The Gram characterization of bacteria was determined by dark purplish or pink color under microscope light at 100X magnification. Moreover, ten of bacterial cells were measured (modified from [22]).

\section{Flagella staining}

A drop of 1-day old bacterialsuspension was placed in a microscope slide. The bacteria were stained with Leifson's solution for $7 \mathrm{~min}$, then with $1 \%$ methylene blue for $5 \mathrm{~min}$. Finally, the bacterial flagella were observed by using the microscope at 100X magnification [22].

\section{Oxidation/Fermentation test}

A bacterial loop was added into each test tube containing $5 \mathrm{~mL}$ of Huge-Leifson medium. Liquid paraffin was added onto a fermentative tube with a thick layer approximately $1.5 \mathrm{~cm}$ to prevent air diffusion into the medium. On the positive reaction, blue color of the medium was changed to yellow one. In contrast, the reaction was negative[22].

\section{Fluorescent pigment production test}

The bacteria were cultured onto test tubes containing $5 \mathrm{~mL}$ of King's B medium for 36 hours. The fluorescent pigment was examined by using ultraviolet lightin a dark chamber [22].

\section{Levan production test}

The bacteria were streaked onto nutrient agar medium $(0.3 \%$ beef extract, $0.5 \%$ peptone, $1.5 \%$ agar) containing $5 \%$ sucrose. After 3 to 5 days, on positive result, a convex, white, domed and mucoid ring of levan was produced around bacterial colonies [22].

\section{Potato soft rot test}

A potato tube was washed under tap water, then with EtOH 70\%. Later, it was cut into 7-8 mm thick slices, and placed in a petri dish. A bacterial loop or a drop of sterile DI water was placed at the center of potato slices. The reaction was positive when decay symptom happened after 24 hours. In contrast, the test was negative[22].

\section{Citrate utilization test}

The bacterium was streaked onto Simmon's citrate agar medium $(0.2 \%$ sodium citrate, $0.02 \%$ $\mathrm{MgSO}_{4} .7 \mathrm{H}_{2} \mathrm{O}, 0.1 \% \mathrm{NH}_{4} \mathrm{H}_{2} \mathrm{PO}_{4}, 0.2 \% \mathrm{~K}_{2} \mathrm{HPO}_{4}, 0.5 \% \mathrm{NaCl}, 0.008 \%$ Bromothymol blue, $1.5 \%$ agar). On positive reaction, the medium color was changed to blue from green [23].

\section{Gelatin liquefaction test}

Test tubes containing $10 \mathrm{~mL}$ of nutrient both $(0.3 \%$ beef extract, $0.5 \%$ peptone) were added by full loops of the bacteria, sealed by paraffin film. One time per day, up to day 15 , the test tubes were tilted after theywere kept at $5^{\circ} \mathrm{C}$ for $15 \mathrm{~min}$ to determine liquefaction of gelatin[22].

\section{Indole production test}

A loop of the bacterial colonies was added into a test tube containing $10 \mathrm{~mL}$ of indole medium ( $1 \%$ tryptone, $0.1 \%$ L-tryptophan). The test tube was then sealed by paraffin film. At 2 and 5 days after incubation, $2.5 \mathrm{~mL}$ of Kovac's indole reagent $(0.5 \% \mathrm{p}$-Dimethylaminobenzaldehydein amyl alcohol : $\mathrm{HCl}$ concentrated with ratio of 3:1) was added onto the test tube to determine indole production. In positive reaction, the medium color inside the test tube was changed to cherry red[22]. 
Vol. 5, No. 04; 2020

ISSN: $2456-8643$

\section{$\mathrm{H}_{2} \mathrm{~S}$ production test}

A Whatman paper was cut into strips of $1 \times 10 \mathrm{~cm}$ size which were soaked onto $10 \%$ copper sulfate solution for $2 \mathrm{~h}$, then air-dried. A loop of the bacterial colonies was added into a test tube containing $5 \mathrm{~mL}$ of $\mathrm{H}_{2} \mathrm{~S}$ production test medium $\left(0.05 \% \mathrm{NH}_{4} \mathrm{H}_{2} \mathrm{PO}_{4}, 0.05 \% \mathrm{~K}_{2} \mathrm{HPO}_{4}, 0.02 \%\right.$ $\mathrm{MgSO}_{4} .7 \mathrm{H}_{2} \mathrm{O}, 0.5 \% \mathrm{NaCl}, 0.5 \%$ yeast extract, $0.05 \%$ peptone). After that, the copper sulfate $\left(\mathrm{CuSO}_{4}\right)$ strip was suspended over the medium containing bacteria. The test tube was sealed by paraffin film. On the positive result, the color of copper sulfate strip was changed from black to light green (modified from [22]).

\section{Urease production test}

Test tubes containing $5 \mathrm{~mL}$ of urease test medium $\left(0.05 \% \mathrm{NH}_{4} \mathrm{H}_{2} \mathrm{PO}_{4}, 0.05 \% \mathrm{~K}_{2} \mathrm{HPO}_{4}, 0.02 \%\right.$ $\mathrm{MgSO}_{4} .7 \mathrm{H}_{2} \mathrm{O}, 0.5 \% \mathrm{NaCl}, 1 \%$ yeast extract, $0.008 \%$ bromothymol blue, $2 \%$ urea) were added loops of bacteria, sealed by paraffin. The medium color was changed from green to blue on the positive reaction(modified from [22]).

\section{Starch hydrolysis test}

The bacterial colonies were streaked onto starch hydrolysis medium $(0.3 \%$ beef extract, $0.5 \%$ peptone, $1.5 \%$ agar, $2 \%$ starch) on petri dishes. At 4 days after incubation, a clear zone appeared around the bacterial colonies on the positive reaction. In contrast, the test was negative[22].

\section{Catalase production test}

One $\mathrm{mL}$ of $3 \%$ hydrogen peroxide $\left(\mathrm{H}_{2} \mathrm{O}_{2}\right)$ solution was dropped onto the bacterial colonies. When catalase was produced from the bacteria, it can react to $\mathrm{H}_{2} \mathrm{O}_{2}$ to produce $\mathrm{H}_{2} \mathrm{O}$ and $\mathrm{O}_{2}$, leading to create bubbles [22].

\subsection{Pathogenicity test}

The experiment was performed in completely randomized design (CRD), 5 replications, 19 treatments including 18 bacterial trains and a non-inoculated control. The bacterial strains were grown on King's B medium at $28 \pm 2{ }^{\circ} \mathrm{C}$ for 4 days, then suspended in sterile DI water, adjusted to $1 \times 10^{7} \mathrm{CFU} \mathrm{mL}{ }^{-1}$. Sterile needles were used to create wounds on pennywort laminas. Bacterial suspension at a volume of $0.1 \mathrm{~mL}$ was dropped on the wound. The plants were put at an inoculation room at $25 \pm 2{ }^{\circ} \mathrm{C}$ for $24 \mathrm{~h}$, with relative humidity at approximately $98 \%$. Then, the inoculated plants were put at a net-house, and disease symptoms were observed everyday. Diameter of lesions were measured at 7 days after inoculation. After this experiment, the most aggressive strain of bacterial pathogen was chosen to do on the following experiments.

2.18 Survey on damage of post-harvest Centella vegetable caused by the most aggressive causal bacteria

The experiment was performed in CRD, three treatments including inoculated lamina part, inoculated petiole part and non-inoculated control, 4 replications. The Indian pennywort plants grown at net-house conditions were collected to perform in the experiment. The bacterial strain was grown on King's B medium at $28 \pm 2{ }^{\circ} \mathrm{C}$ for 4 days, then suspended in sterile DI water, adjusted to $1 \times 10^{7} \mathrm{CFU} \mathrm{mL} \mathrm{mL}^{-1}$. Sterile needles were used to create wounds on pennywort laminas or petioles. Bacterial suspension at a volume of $0.1 \mathrm{~mL}$ was dropped on the wound. The inoculated pennywort was placed on moist tissue paper onto petri dishes. Symptoms were observed everyday and measured at 2 days after inoculation. 
Another experiment was performed in CRD, four replications, with dipping method,consisting of dipping treatment on a bacterial suspension and dipping treatment on sterile DI water. The Indian pennywort plants, bacterial strain and its solution were prepared similar to the previous experiment. Symptoms of the plants were recorded at 2 days after inoculation.

\section{RESULTS}

Samples of diseased pennywort plants were collected at eighteen fields in three Vietnam's provinces including Hau Giang, Can Tho and Tien Giang. Total 18 bacterial strains were purified and applied on a procedure of Koch's postulate.

The symptoms in pennywort petioles inoculated was shown in Figure 1. At 2 days after inoculation (DAI), a blight lesion was formed on rhombus shape with gray center, water-soaked margin and a size of approximately $2 \times 1.5 \mathrm{~mm}$. At 4 DAI, the lesions could develop up to $4 \mathrm{x}$ $2.5 \mathrm{~mm}$ of size. The lesions were scabrous, wrinkled and necrotic. They could coalesce to form blight symptom of a part or whole petiole. The petioles collapsed at 6 DAI (Figure 1A-D). On the control treatment, there was no symptom on petioles (Figure 1E).
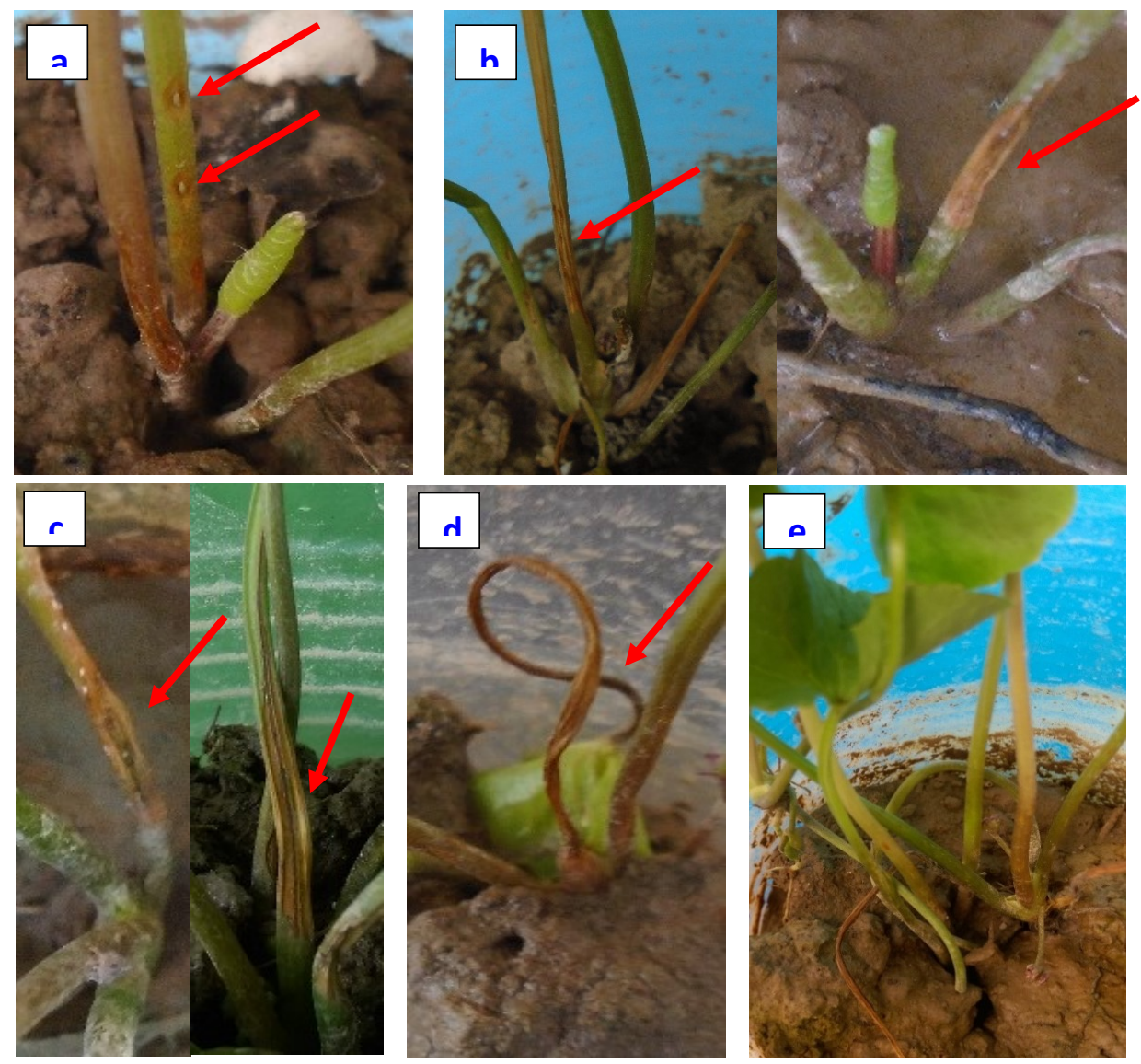

Figure 1: Symptoms of pennywort petioles of C. asiatica inoculated with bacterial pathogen

(a): Water-soaked symptom was appeared at needle lesions

(b): Blight lesions were extended 
(c): Blight lesions were scabrous, surface- wrinkled and necrotic

(d): Petioles were collapsed

(e): Petioles control

The symptoms in pennywort lamina inoculated was shown in Figure 2. At 2 DAI, lesions were circle-shaped or irregular, concave, brown to gray, with graylish margin. After 2 days, the lesions developed but was limited by lamina veins (Figure 2A-B). There was no symptom on the pennywort lamina inoculated with sterile DI water. These symptoms were similar to those at pennywort fields (Figure 3).
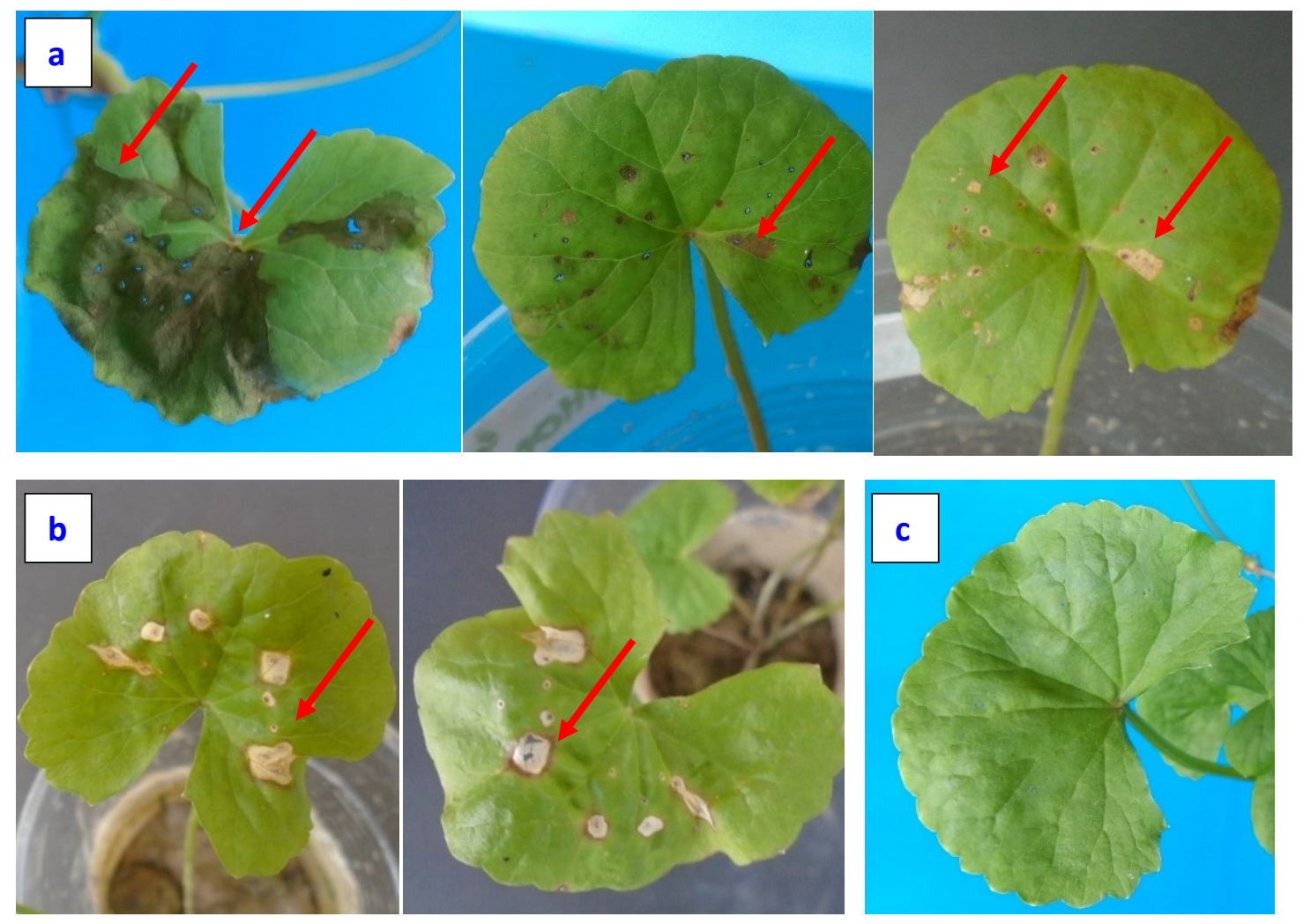

Figure 2: Symptoms of pennywort laminas of $C$. asiatica inoculated with bacterial pathogen

(a): Initial lesions were brown, then turning to gray

(blight lesions), which tends to be limited by leaf veins

(b): Purple halos were appeared around old-lesions

(c): The lamina control 


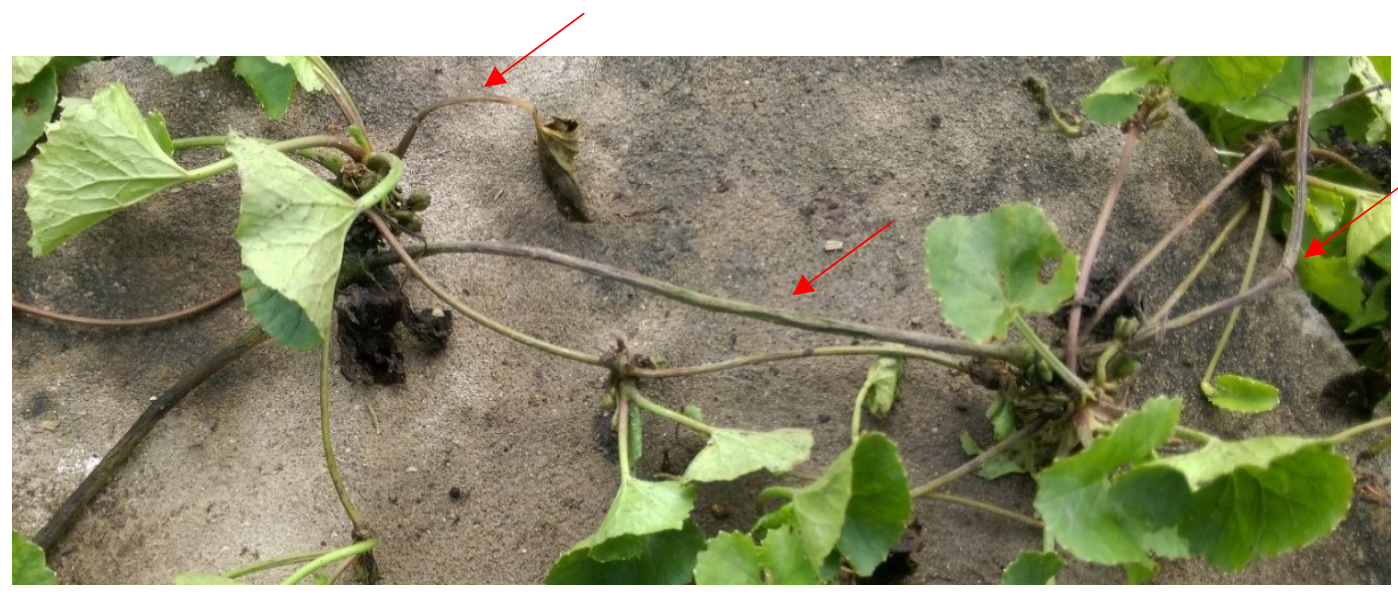

Figure 3: Symptoms of bacterial blight on Indian pennywort at fields in Hau Giang province, Vietnam

\subsection{Identification of bacterial strains}

The bacterial strains were identified as the causal pathogen of Indian pennywort blight disease by characteristics of morphology, Gram, biochemical reactions and disease symptoms (Table 1). The single colony of the bacterial isolates were circular of form, white color, convex of elevation, entire of margin and not mucoid. The cells of the bacteria were rod-shaped, with approximately $2.35 \times 0.9 \mu \mathrm{m}$ of size, Gram-negative and polar flagella (Figure 4).

Table 1: The characters of morphology, biochemical and host of bacterial strain H1-3 and P. marginalis

\begin{tabular}{|c|c|c|c|c|c|c|c|c|}
\hline \multirow{2}{*}{ Character } & \multirow{2}{*}{$\begin{array}{l}\text { Bacteri } \\
\text { al strain } \\
\text { H1-3 }\end{array}$} & \multicolumn{7}{|c|}{ Characters of $P$. marginalis } \\
\hline & & {$[23]$} & {$[22]$} & [24] & [25] & [26] & [27] & {$[28]$} \\
\hline Host & $\begin{array}{l}\text { Indian } \\
\text { pennyw } \\
\text { ort }\end{array}$ & Plants & Plants & $\begin{array}{l}\text { Lettu } \\
\text { ce }\end{array}$ & $\begin{array}{l}\text { Onio } \\
\mathrm{n}\end{array}$ & $\begin{array}{l}\text { Dumbca } \\
\text { ne }\end{array}$ & $\begin{array}{l}\text { Potat } \\
\text { o }\end{array}$ & Onion \\
\hline Shape & Rod & $\begin{array}{l}\text { Rod } \\
\text { or } \\
\text { curve } \\
\text { d }\end{array}$ & & & Rod & & Rod & \\
\hline
\end{tabular}




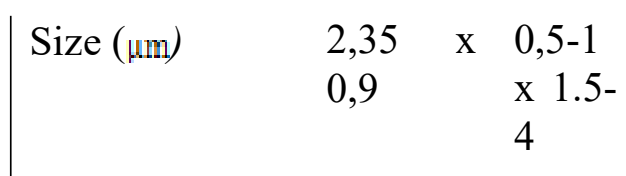

\begin{tabular}{|c|c|c|c|}
\hline Flagella & Polar & Polar & $\begin{array}{l}1-3 \\
\text { polar }\end{array}$ \\
\hline
\end{tabular}

Gram

$\mathrm{KOH}$ solubility $\quad+\quad+\quad+$

Oxidation/Fer +/ $\quad$ + - - $\quad+/-\quad+/ \quad+/ \quad+/$ mentation

Fluorescent $\quad+\quad+\quad+$ pigment production

Levan production

Potato soft rot $\quad+\quad+\quad+$

Gelatin

liquefaction

Starch

hydrolysis

Urease

production

Catalase $\quad+$

production

Citrate

Utilization

Indole

production

$\mathrm{H}_{2} \mathrm{~S}$ production

+ positive - negative



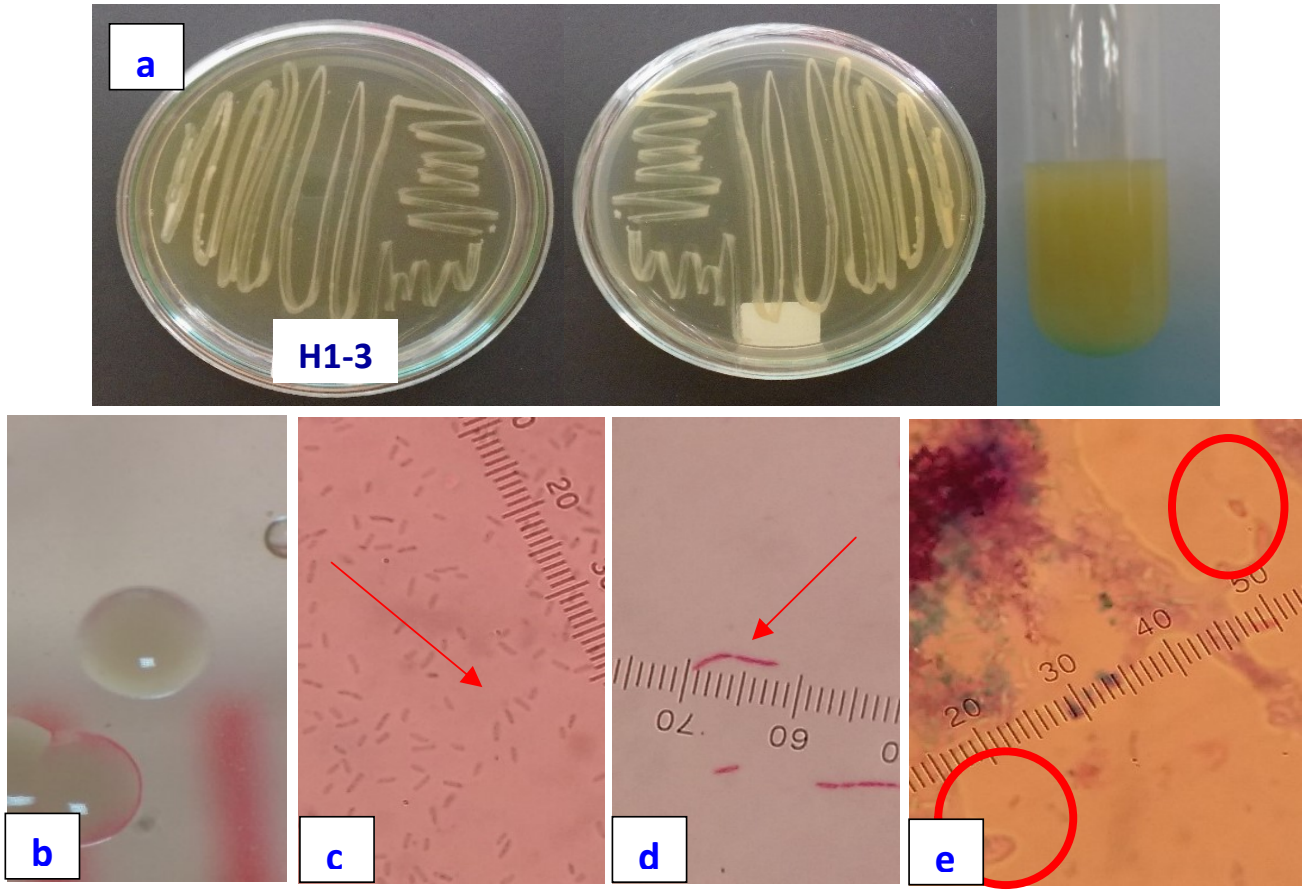

Figure 4: Morphology characters of bacterial pathogen

(a): 5 days-old colonies and bacterial suspension

(b): Single colony of the bacteria was circular, elevated and not mucoid

(c): Bacterial cells

(d): Gram staining

(e): Polar flagella

The biochemical characters were positive of gelatin liquefaction, catalase production, citrate utilization, indole production, oxidation, fluorescent pigment production, Levan production, and negative of starch hydrolysis, fermentation, urease production and $\mathrm{H}_{2} \mathrm{~S}$ production (Figure 5). Based on these previous characteristics, the causal pathogen of Indian pennywort blight disease was Pseudomonas marginalis. 
Vol. 5, No. 04; 2020

ISSN: $2456-8643$
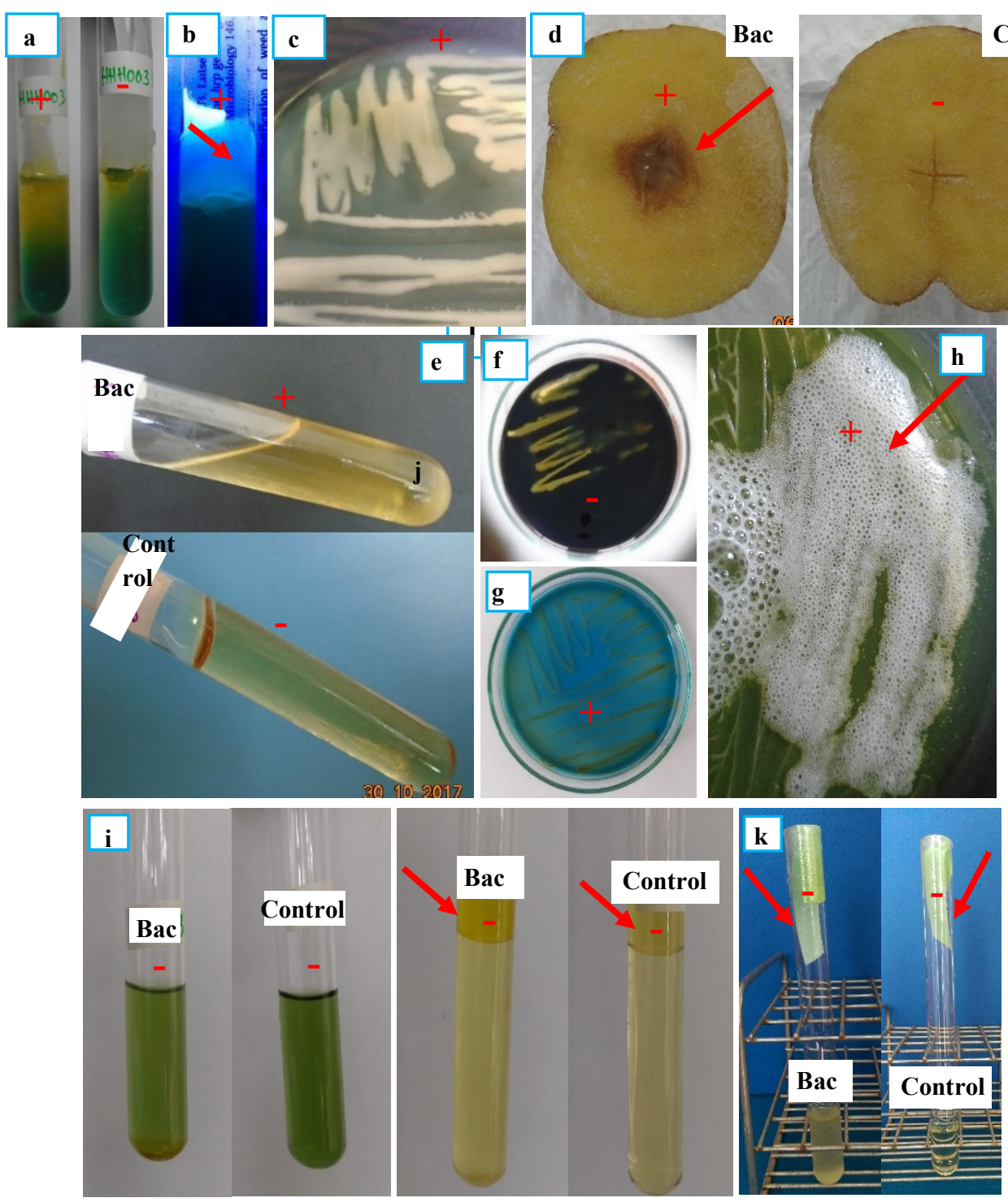

Figure 5: Biochemical characteristics of bacterial pathogen

(a): Oxidation (left) and Fermentation (right) test; (b): Fluorescent pigment production test; (c): Levan production test; (d): Potato soft rot test; (e): Gelatin liquefaction test; (f): Starch hydrolysis test; (g): Citrate utilization test; (h): Catalase production test; (i): Urease production test; (j): Indole production test; $(\mathrm{k})$ : $\mathrm{H}_{2} \mathrm{~S}$ production test. Bac: bacterial pathogen; +: positive; -: negative

\subsection{Pathogenicity test}

The pathogenicity test was conducted to aim detect the most aggressive strain of bacterial blight pathogen in Indian pennywort in total 18 of the bacteria strains isolated. Among these bacterial strains, the strain of H1-3, isolated at Hau Giang pennywort field, showed the highest severity. 
This aggressive strain was chosen to survey effect of bacterial blight disease on post-harvest Centella vegetable.

\subsection{Damage of post-harvest Centella vegetable caused by Pseudomonas marginalis}

Effect of $P$. marginalis on post-harvest stage of Centella was surveyed on two separated experiments with different methods. On the method of needle inoculation, the symptoms on pennywort laminas were soft-rotting areas at approximately $0.4-1 \mathrm{~cm}$, that appeared at 2 days after inoculation. On pennywort petioles, the symptoms were small soft rots at inoculation points, lower damage than those of laminas (Figure 6). The diameter of rot lesions on pennywort laminas and the length of rot lesions on pennywort petioles were $0.698 \pm 0.248,4.35 \pm 1.047 \mathrm{~cm}$, respectively (Table 2). On the method of suspension dip, the lamina symptoms were dried-wilt with greenish gray color. The pennywort petioles dipped into the bacterial suspension had softrot, transparent brown lesions. However, the pennywort petioles dipped into sterile DI water showed non dried-wilt (Figure 7). The diameters of dried-wilt lesions on pennywort laminas and the length of rot lesions on suspension-dipped petioles, control petioles were $2.975 \pm 0.126$ and $5.95 \pm 0.625,0 \pm 0 \mathrm{~cm}$, respectively (Table 2 ).

Table 2: Diameter $(\mathrm{cm})$ of lesions in lamina and length $(\mathrm{cm})$ of lesions in petiole at 2 days after inoculation

\begin{tabular}{|lll|}
\hline & $\begin{array}{l}\text { Innoculation } \\
\text { treatment }\end{array}$ & $\begin{array}{l}\text { Dipping } \\
\text { treatment }\end{array}$ \\
\hline $\begin{array}{l}\text { Pennywort } \\
\text { lamina }\end{array}$ & $0.698 \pm 0.248$ & $2.975 \pm 0.126$ \\
$\begin{array}{l}\text { Pennywort } \\
\text { petiole }\end{array}$ & $4.35 \pm 1.047$ & $5.95 \pm 0.625$ \\
\hline
\end{tabular}
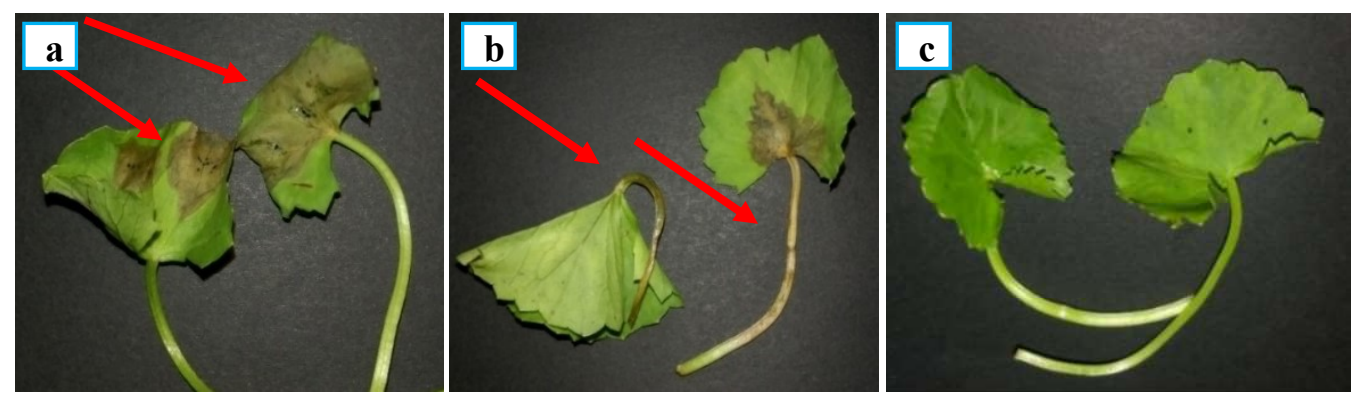

Figure 6: Symptoms of post-harvest $C$. asiatica inoculated with $P$. marginalis H1-3 (a): Inoculated laminas; (b): Inoculated petioles; (c): Sterile DI water control 

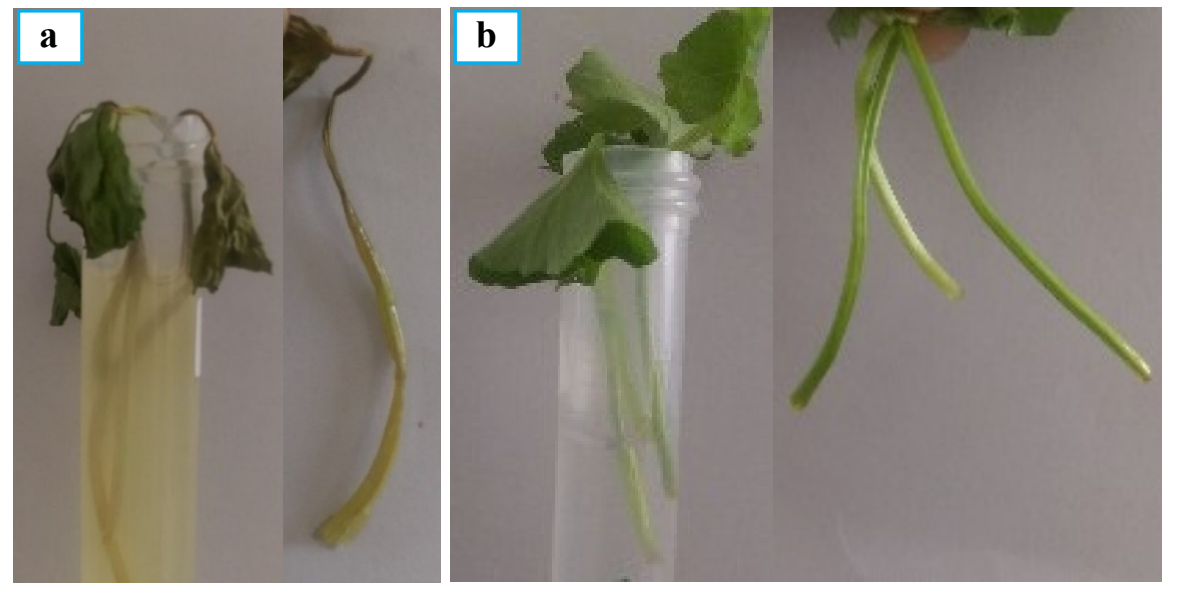

Figure 7: Symptoms of post-harvest $C$. asiatica soaked with $P$. marginalis H1-3 suspension (a): P. marginalis H1-3 suspension; (b): Sterile DI water control

\section{DISCUSSION}

The bacterial strains purified in the research caused the blight symptoms in the laminas and petioles of Indian pennywort. The bacteria were characterized by aerobic trait, negative Gram and fluorescent production onto King's B medium. In addition, the bacteria have polar flagella and rod shape with approximately $2.35 \times 0.9 \mu \mathrm{m}$ of size, which were also matched with a description of Pseudomonas genus by [23]. Besides, the Pseudomonas bacteria showed many valuable traits on biochemical tests. The bacteria could use glucose to create acid, leading to a reduction of media $\mathrm{pH}$ on positive oxidation/fermentation test. Next, the bacteria could utilize sucrose as sole carbon source to produce levan, use citrate or ammonium salt as a sole source of carbon or nitrogen, respectively. Moreover, the bacteria could produce gelatinase, resulting in the liquefaction of gelatin. Enzyme tryptophanase of the bacteria formed indole. Another enzyme of desulfohydrase from the bacteria produced $\mathrm{H}_{2} \mathrm{~S}$. Similarly, the Pseudomonas could secrete enzyme urease to produce $\mathrm{NH}_{3}$. Lastly, the Pseudomonas could produce enzyme amylase to hydrolysis of starch. These positive or negative traits of biochemical reactions further characterized that the bacterial pathogen was Pseudomonas marginalis[22]. These biochemical traits were similar to characters of Pseudomonas marginalis in other vegetables including lettuce, onion, dumbcane and potato [24] [25][26][27][28].

At present, this is the first report of $P$. marginalis in C. asiatica. The pathogen $P$. marginalis was reported to cause soft rot in Allium cepa L. in New Zealand [25] and Morocco [28]; soft rot of Zantedeschia spp. in Czech Republic [29]; rot of Leucojumaestivum in Bulgaria [30]; brown vein, leaf spot and marginal leaf blight of Lactucasativa L. in USA [24]; marginal blight of Cucumissativus in Japan [31]; bacterial blight in petioles and firm rot in roots of Pastinacasativa L. [32]; leaf spot and blight of Dieffenbachiaamoena in Italy [26]; blossom blight of Fragaria x ananassa in USA [33].These researches showed that the pathogen of $P$. marginalis could create two types of symptom, including soft rot and blight. The type of soft rot appeared on tuber 
Vol. 5, No. 04; 2020

ISSN: $2456-8643$

tissues of plants such as onion[25][28], potato [27], Zantedeschia spp. [29], summer snowflake [30]. Meanwhile, blight symptom appeared at leaf tissues of plants such as lettuce [4], cucumber [31], parsnip [32], dumbcane [26], strawberry [33]. Carbohydrates produced at source sites such as leaf tissues, and transported to sink sites such as tuber tissues. This suggested that more or less carbohydrates could affect to symptom expression caused by $P$. marginalis. In the other hand, on the post-harvest stage, the lamina of Indian pennywort plants still photosynthesized, but carbohydrateswere accumulated in the photosynthesis sites. Therefore, the soft rot symptom appeared at both petioles and laminas of pennywort plants, while blight symptom was at laminas. In the farmers' fields, the disease pattern of Indian pennywort was at holes with diameter at approximately 40-60 cm, mostly at low-lying soil and wounded plants. This was similar to a description of Hunter and Cigma [32] in parsnip fields. These authors indicated that at areas of low-lying soil at the fields, $P$. marginalis attacked the wounded parsnip plants and an accumulation of irrigated water created a spread of the Pseudomonas, leading to create big disease holes at the fields. On the period of sample collection at Hau Giang, Can Tho and Tien Giang provinces, a disease phenomenon was also recorded. When the sunlight appeared after a heavy rain, the bacterial blight in $C$. asiatica was quickly and severely occurred at the fields. This phenomenon was in line with a research of Berger [24]. The author indicated that rain water could favour the movement and spread of bacterial pathogens at the vegetable fields.

At wholesale or retail vegetable market in Vietnam, the Indian pennywort was cut and packed at plasticbags at approximately 5-10 kg each. The Indian pennywort vegetable was rotted quickly inside plasticbags. Therefore, the remain question is which way the Pseudomonas pathogen could invade and damage on pennywort vegetables. The results of this research showed that bacterial pathogens could invade pennywort vegetable through cutting position of petioles. The harvest tools could carry bacterial pathogens from diseased pennywort to healthy ones. Aremu and Babolola [34] and Plantwise Knowledge Bank [35] found that the P. marginalisis a secondary invasive or opportunistic pathogen that could infect the plant host through wounds or natural openings.

\section{CONCLUSION}

Pseudomonas marginalisis the causal agent of bacterial blight disease in C. asiaticaat Vietnam. In addition, $P$. marginalisis also the cause of soft rot phenomenon in post-harvest pennywort vegetable at the market. This is the first report of $P$. marginalisin Indian pennywort plants. An effective control of this disease will be carried out on further researches.

\section{REFERENCES}

[1] S.E. Edwards, I. da Costa Rocha, M. Heinrich, E.M. Williamson, Phytopharmacy: an evidence-based guide to herbal medicinal products ( $1^{\text {st }}$ edition), John Wiley \& Sons, 414p, 2015. [2] D.H. Bich, D.Q. Chung, B.X. Chuong, N.T. Dong, D.T. Dam, P.V. Hien, V.N. Lo, P.D. Mai, P.K. Man, D.T. Nhu, N. Tap, Medicinal Herbs and Animals in Viet Nam (Vol. 2), Vietnam Science and Technology Press, 1255p, 2004.

[3] C.J. Zheng, L.P. Qin, "Chemical components of Centella asiatica and their bioactivities", Journal of Chinese Integrative Medicine, 5 (3), pp. 348-351, 2007.

[4] S. S. Jamil, N. Qudsia, S. Mehboobus, “Centella asiatica (Linn.) Urban - A review”, Natural Product Radiance, 6 (2), pp. 158-170, 2007. 
Vol. 5, No. 04; 2020

ISSN: $2456-8643$

[5] C.L. Cheng, J.S. Guo, J. Luk, M.W.L. Koo, "The healing effects of Centella extract and asiaticoside on acetic acid induced gastric ulcers in rats", Life Sciences, 74 (18), 2237-2249, 2004.

[6] J. Somboonwong, M. Kankaisre, B. Tantisira, M.H. Tantisira, "Wound healing activities of different extracts of Centella asiatica in incision and burn wound models: an experimental animal study", BMC Complementary and Alternative Medicine, 12 (1), p. 103, 2012.

[7] B.H.I. Ruszymah, S.R. Chowdhury, N.A.B.A. Manan, O.S. Fong, M.I. Adenan, A.B. Saim, "Aqueous extract of Centella asiatica promotes corneal epithelium wound healing in vitro", Journal of Ethnopharmacology, 140 (2), pp. 333-338, 2012.

[8] Maulidiani, F. Abas, A. Khatib, V. Perumal, V. Suppaiah, A. Ismail, M. Hamid, K. Shaari, N.H. Lajis, "Metabolic alteration in obese diabetes rats upon treatment with Centella asiatica extract", Journal of Ethnopharmacology, 180, pp. 60-69, 2016.

[9] G. Visweswari, K.S. Prasad, P.S. Chetan, V. Lokanatha, W. Rajendra, "Evaluation of the anticonvulsant effect of Centella asiatica (gotu kola) in pentylenetetrazol-induced seizures with respect to cholinergic neurotransmission", Epilepsy \& Behavior, 17 (3), pp. 332-335, 2010.

[10] P. Kalshetty, U. Aswar, S. Bodhankar, A. Sinnathambi, V. Mohan, P. Thakurdesai, "Antidepressant effects of standardized extract of Centella asiatica L. in olfactory bulbectomy model", Biomedicine \& Aging Pathology, 2 (2), pp. 48-53, 2012.

[11] S.R. Jared, "Enhancement of memory in rats with Centella asiatica", Biomedical Research, 21 (4), pp. 429-432, 2010.

[12] M.A. Abdulla, F.H. Al-Bayaty, L.T. Younis, M.A. Hassan, "Anti-ulcer activity of Centella asiatica leaf extract against ethanol-induced gastric mucosal injury in rats", Journal of Medicinal Plants Research, 4 (13), pp 1253-1259, 2010.

[13] C. Manoharachary, I.K. Kunwar, K.S. Babu, "A new leaf spot of Centella asiatica caused by Cercospora centellae sp.", Journal of Mycology and Plant Pathology, 33 (2), pp. 271-273, 2003.

[14] T.R. Parashurama, M. Parinitha, G.E. Mallikarjunaswamy, M.B. Shivanna, "Cercospora leaf spot disease in Centella asiatica and its effect on pharmaceutical components", International Journal of Biological \& Pharmaceutical Research, 4 (1), pp. 64-71, 2013.

[15] J.H. Park, M.J. Park, S. Wolcan, H.D. Shin, "First report of Septoria centellae associated with leaf spot of Centella asiatica in Korea", Mycobiology, 39 (4), pp. 310-312, 2011.

[16] C. Debjani, B. Dasgupta, P.C. Paul, "Studies on leaf spot of Centella asiatica caused by Alternaria sp.", in Proceedings of The International Symposium on Minor Fruits and Medicinal Plants for Health and Ecological Security (ISMF \& MP), December 19 - December 22, 2011, West Bengal, India, pp 237-241, 2012.

[17] D.H.S. Gracelin, D. Herin, A.J. De Britto, R. Kumar, P.B. Jeya, "Detection and identification of Xanthomons cempestris pv. centellae on leaves of Centella asiatica collected in Tamilnadu", Asian Journal of Pharmaceutical and Clinical Research, 5 (1), pp. 111-113, 2012.

[18] D. Hargono, P. Lastari, Y. Astuti, M.H. van den Bergh, "Centella asiatica (PROSEA)," uses.plantnet-project.org, Jan. 25, $2016 . \quad$ [Online].http://uses.plantnetproject.org/en/Centella asiatica (PROSEA) [Acessed: Mar. 15, 2020].

[19] B. Mondal, D.C. Khatua, "White rot of Centella asiatica and two weeds in West Bengal, India", Journal Crop and Weed, 11 (1), pp. 225-226, 2015. 
Vol. 5, No. 04; 2020

ISSN: $2456-8643$

[20] L.W. Burgess, T.E. Knight, L. Tesoriero, H.T. Phan, Diagnostic Manual for Plant Diseases in Vietnam ( $1^{\text {st }}$ edition), Australian Centre for International Agricultural Research (ACIAR), 210p, 2008.

[21] B.F. Oriowo, S.O. Bankole, A.B. Alarape, D.A., "Isolation, identification and characterization of seed borne pathogen associated with kenaf (Hibiscus canabinus)", International Journal of Agriculture, Environment and Bioresearch, 4 (5), 43-54, 2019.

[22] T. Goszczynska, J.J. Serfontein, S. Serfontein, Introduction to Practical Phytobacteriology ( $1^{\text {st }}$ edition), ARC-Plant Protection Research Institute, 91p. 2000.

[23] N.W. Schaad, J.B. Jones, W. Chun, Laboratory Guide for the Identification of Plant Pathogenic Bacteria (third edition), American Phytopathological Society (APS) Press, 373p, 2001.

[24] R.D. Berger, "Marginal leaf blight of lettuce",in Proceedings of the Florida State Horticultural Society, 80, pp 134-138, 1967.

[25] P.J. Wright, C.N. Hale, "A field and storage rot of onion caused by Pseudomonas marginalis," New Zealand Journal of Crop and Horticultural Science, 20 (4), pp. 435-438, 1992.

[26] M. Scortichini, "Leaf spot and blight of Dieffenbachia amoena caused by Pseudomonas marginalis pv. marginalis", Plant Pathology, 43 (5), pp. 941-943, 1994.

[27] J. Li, Z. Chai, H. Yang, G. Li, D. Wang, "First report of Pseudomonas marginalis pv. marginalis as a cause of soft rot of potato in China", Australasian Plant Disease Notes, 2 (1), pp. 71-73, 2007.

[28] E.H. Achbani, S. Sadik, R. El Kahkahi, A. Benbouazza, H. Mazouz, "First report on Pseudomonas marginalis bacterium causing soft rot of onion in Morocco", Atlas Journal of Biology, 3 (2), pp 218-223, 2014.

[29] V. Krejzar, J. Mertelík, I. Pánková, K. Kloudová, V. Kudela, "Pseudomonas marginalis associated with soft rot of Zantedeschia spp.”, Plant Protection Science, 44 (3), pp. 85-90, 2008.

[30] M. Stoyanova, L. Georgieva, P. Moncheva, N. Bogatzevska, "Burkholderia gladioli and Pseudomonas marginalis pathogens of Leucojum aestivum", Biotechnology \& Biotechnological Equipment, 27 (5), pp. 4069-4073, 2013.

[31] K. Ohta, H. Morita, K. Mori, M. Goto, "Marginal blight of cucumber caused by a strain of Pseudomonas marginalis (Brown) Stevens", Japanese Journal of Phytopathology, 42 (2), pp. 197-203, 1976.

[32] J.E. Hunter, J.A. Cigna, "Bacterial blight incited in parsnip by Pseudomonas marginalis and Pseudomonas viridiflava", Phytopathology, 71 (12), pp. 1238-1241, 1981.

[33] C.T. Bull, A.I. Huerta, S.T. Koike, "First report of blossom blight of strawberry (Fragaria $\times$ ananassa) caused by Pseudomonas marginalis", Plant Disease, 93 (12), p1350, 2009.

[34] B.R. Aremu, O.O. Babalola, "Classification and taxonomy of vegetable macergens", Frontiers in Microbiology, 6, p 1361, 2015.

[35] Plantwise Knowledge Bank, "Lettuce marginal leaf blight (Pseudomonas marginalis pv. marginalis)",in Plantwise Technical Factsheet, plantwise.org (2018). [Online]. Source: https://www.plantwise.org/KnowledgeBank/ Datasheet.aspx?dsid=44979 [Assessed: Feb. 17, 2020]. 